\title{
Review of \\ From Big Bang to Galactic Civilizations: A Big History Anthology
}

Jon Cleland Host

Correspondence | Jon Cleland Host, equinoxjjh@yahoo.com

Citation | Host, J.C. (2019) Crater, Catastrophe, Contingency: An Improbable Journey and

the Human Situation: A Review of From Big Bang to Galactic Civilizations: A Big History Anthology, III(2); $115-119$.

DOI | http://dx.doi.org/10.22339/jbh.v3i2.3270

\section{e ntroduction}

Big History is increasingly important in many ways in our world today. In light of this growth, it is both timely and helpful that Primus has published From Big Bang to Galactic Civilizations: A Big History Anthology. This three volume compendium of essays offers a wideranging and highly varied window into this exciting field.

Many of these essays tap into the wonder and grandeur of Big History. The wonder and granduer that I felt from the field of Big History before this field also shared that name. My first glimpse into this wonder came very early. As a child, my siblings and I were encouraged to investigate the world around us, including the woods near our house that were abundant in discoveries waiting to be found. There, hills became ancient mountain forts, moss covered logs became huge beasts, and simple depressions in the ground became dinosaur footprints. These marvels brought the woods to life, each in its own way. Then, in 1980, my dad introduced me to Carl Sagan's Cosmos series. This opened my eyes to our Universe - showing both marvels far beyond the neighboring woods, and also showing how much more marvelous (in both deep time and in microscopic form) all of the things in the woods actually were. Most importantly, by showing the deep time history of our Universe what we now know as "Big History"- all of these little miracles now formed a seamless whole, connected to each other through time and history to become the awesome Universe, which also includes me! As Big History brings our formerly separate academic fields together in a unified whole, I'm thrilled to see it spreading and bringing deeper understanding to students, to teachers, and to others worldwide today.

Like the many disciplines Big History unifies, this set of essays has a lot of variety. This variety spans many different areas: some essays are concerned with the whole sweep of history while others are focused on comparatively tiny regions, there are essays by authors with diverse cultural backgrounds, essays based strictly on current evidence as well as more speculative essays about the past, present, and the future. This variety not only grows from the different topics of these essays, but also from the many different academic disciplines they hail from. Though all of these three volumes are about the overall topic of Big History, they have very different flavors and areas of emphasis.

\section{Volume 1:}

The First Volume is titled "Our Place in the Universe: An Introduction to Big History". True to its name, the anthology leads with essays From Roberta Bondar, Siegfried Kutter, Walter Alvarez, and David Christian which give a clear and engaging overall view of Big History.

Roberta Bondar (space traveler, scientist, and education champion) opens the anthology with one of the most important points of Big History - that 
Big History helps show that the boundaries between disciplines are human constructions and that our body of knowledge is one body of knowledge. She does this by making the powerful and insightful analogy to the view of Earth from space, where similar human-made national boundaries cannot be seen. This realization, that all of the areas of knowledge can form a unified whole, just as our world does around us, is one of the most important realizations of Big History, one that has been important in my life and especially in sharing the joy and excitement of our Universe with both my children and my students. Approaching all academic disciplines as simply additional facets of the same incredible body of knowledge was something that I learned (perhaps unintentionally) from my dad, as he showed us the discoveries of space without regard to keeping the disciplines separated. From there, it followed naturally for me to include new knowledge into this growing body of knowledge, organized by stories and connections rather than walls and barriers. From there, the same approach then comes out in my teaching not only in the classroom but also to my own children. This makes both lifelong learning and teaching so much easier as well as more fun! Few things in life can compare to seeing the thrill of discovery spread across the face of the learner (of any age), and knowing that thrill myself.

The following essay by Siegfried Kutter gives information essential to understanding how we got here, and why understanding Big History is a requirement for anyone to be able to make good decisions for our future world. After this, Walter Alvarez gives a glimpse (and even this is just the tip of the iceberg) of the literal mountains of knowledge upon which Big History is built upon.

Deeply personal stories can be found in the middle of Volume 1, including the touching story of Antonio Velez and Barry Rodrigue's reminder of what Robby the Robot teaches us. Robby's lesson that technology alone (without a lot of human effort) can't save us, is an important complement to the many technologically future focused essays, found especially in Volume 3.

One of the most important points from Volume 1 can be found in two excellent essays by Alexander Mirovic and Nigel Hughes. Both essays help us see that all ideas are not equally true, some are well supported by evidence and some are not. While this is obvious to many of us, there are places where relativism is so strong that the very idea of one using evidence to decide between ideas is questioned. This is especially relevant to Big History because the very same mountains of knowledge referenced above- upon which Big History and indeed, humanity's discoveries over the past dozens of thousands of years - rest on foundations of evidence. Without a reliance on evidence, ideas become untestable, and one realizes that then none can be reasonably believed. Thus, drifting away from a reliance on evidence can rob one of all wonders that do exist and leave one searching for more unsupported ideas as a counter productive means to bring awe back into one's life.

This same reliance on evidence is again made clear in the intriguing windows into the deep roots of Tiananmen and Jericho opened by the little big histories of these places by Craig Benjamin and Esther Quaedackers.

The importance of seeing our world as a whole, of inclusion in the decision making process (the polity), of using evidence, and of working for a better world is shown in the essay by Lowell Gustafson, which helps draw together many of the threads weaving through this first volume. These essays come together in Volume 1 to give the reader both a clear view of the facts and approaches of Big History, as well as their importance today.

\section{Volume 2}

With a title of "Education and Understanding" Big 
History Around the World", the second volume of this anthology clearly marks the global scope and impact of Big History.

To begin, the worldwide success of Big History is examined through examples from around the world in the first seven essays (Eric Chaisson, Seohyung Kim, Mojgan Behmand, Barry Rodrigue, Jos Werkhoven, Douglas Northrup, Cameron Gibelyou, and Barry Wood). Each essay is a poignant story centered around growth and experience in teaching this emotionally moving subject (often for decades) and seeing the minds of many students exceeding their expectations. In addition, the essay by Barry Rodrigue points out the important realization that the very structure of the old way of teaching history (including "Western Civilization") was both ethnocentric and exclusionary.

Like volume 1, volume 2 also contains many touching personal stories. These stories reflect the human face within the rise and advancement of Big History. In addition to the many personal aspects of the essays mentioned above, the contributions from Lucy Hawking, Roland Saekow, Rana Singh, Lana Ravandi-Fadai/Kevin McNeer and many others make reading volume 2 a lot like a casual conversation with an old friend. Indeed, the essay by Brian Swimme captures the need for stories themselves For as long as we have been human, our Ancestors have been telling stories. It is stories which give us our roots, which give us a reason to exist, which connect us with those other people we consider to be "like us", and which empower us to work for the future. People remember stories, learn by stories, live by stories, and hope by stories. Brian Swimme reveals the critical importance of our cosmic story, for all of humanity, in serving all of those roles. Not least of those roles is the identification of who is another person to care about. Narrow, nationalistic stories have long closed people off to other humans, stoking hatred and violence. Our cosmic story has begun to reverse this, drawing in all humans, and indeed all life, into our story - fostering inclusion and caring for all. It does so by showing that we are all members of the same family tree; we literally and truly are all realted. Anyone we meet, no matter who they are or what they look like, has parents. Stepping back through those parents to their parents, ever further until we come to an Ancestor who is also one of our Ancestors, creating a direct line of parents and children that leads to us. This realization can mean, if one chooses so, that everyone we meet - and those we don't meet- is a person to care about, a person "like us". Indeed, the same process also links us to everything alive on Earth and only means that we need to go back through a larger number of parents to do so. How can anyone foster racist, nationalistic, or life destroying views after seeing that we are literally all one family? I know I cannot and would not want to. At a time when racism and nationalism are reappearing on our societal landscape (of course they were never gone), these realizations are very relevant today, especially for those of the next generation who have a major role in crafting the world of tomorrow.

It is a clear fact that this connection to all life is essential for our future. This realization is also made clear in William Grassie's essay, which shows that this globally inclusive story could not only reverse the harmful path we are now on, but should we fail to build a just, healthy, and sustainable world, this story is a necessary for civilization's recovery.

Volume 2 comes to a close with an enormous range of voices from many different regions and nations, including China, Somalia, Japan, North Africa, the Caucasus, Iran, and the Middle East. These essays include regional art, the impact and ongoing growth of Big History in these areas, musings on life on other planets and our future, deep local history, ecology, and more. Volume 2 leaves the reader both connected to our global family overall and more aware of the many wonderful stories to be found in specific regions around the world. 


\section{Volume 3}

The previous two volumes of this anthology have given us a solid overview of Big History as well as a global view. The third volume, "The Ways that Big History Works: Cosmos, Life, Society and our Future", extends our gaze far into the future, drawing on what we know about our past $\sim 14$ billion years to try to estimate even the next few centuries on our tiny Earth.

Appropriately, the first essay in this volume (by Kathy Shick \& Nicholas Toth) connects much of the future speculation which follows with our deep time past using our human evolution as a bridge between them. This review is very timely and helpful, especially because so much has been discovered in just the past few decades about our evolution from earlier primates. Compared to the small amount of information known on human evolution just a few decades ago -- the wealth of transitional fossils and DNA evidence-- the data we have today is yet to be understood and well worth analyzing. This review of our primate Ancestors was especially important to me in light of our family connections described earlier. In fact, the ability of so many people to get their direct DNA analyzed today makes DNA evidence more understandable and much closer to home. I've been excited to find the discoveries both in myself and my extended family which personalized DNA testing has uncovered. Suddenly I've been able to find direct links to people around the world, of many different races, while also finding which segments of my own DNA randomly made it to my kids and which did not.

The background, as well as the extensive Big History information from the first two volumes, prepares the reader for the consideration of several proposed frameworks for approaching Big History. These frameworks comprise about half of volume 3. Our human brains are incredibly versatile, and are often able to draw parallels from disparate sets of data parallels which sometimes are due to the same physical process going on in two areas, as well as parallels which are simply mental ways to categorize similar overall phenomena (while some parallels fall somewhere in between). By noticing these parallels, new terms and new overall descriptions of common features can be used to build overall theoretical explanatory frameworks. Some of the many frameworks described in volume 3 are compatible with each other, and even work well together, while others are separate ways to approach Big History as a whole. To me, these many frameworks show that frameworks themselves may fall under a "Goldilocks rule", as does much of Big History. Detailed frameworks, by adding more to study, are less valuable because they decrease simplification in the different areas to which they are applied. At the other extreme, very simple frameworks can explain basic commonalities while missing much of the detail in the various areas of study. Between these two is perhaps a Goldilocks zone: explanatory frameworks which are complex enough to capture important details, while being simple enough to still have explanatory power.

Futuristic speculation makes up the last main section of volume 3. Envisioning the future with any accuracy is very difficult. Yet, after examining the past 14 billion years of history, it's very tempting to at least think about the next few centuries. After all, even the next whole millennium of 1,000 years is only $0.000007 \%$ of our 14 billion year history! Speculation about the future is, of course, speculation, so little beyond the most trivial predictions can be said with certainty. At the same time, so much of our world today would be utterly amazing to our Ancestors from even a few centuries ago, so who knows? While the futures described in this section are often optimistic, they are balanced to some extent by the possibility of a collapse of civilization as described by William Grassie in volume 2. Such as with the various frameworks described above, some of these essays.

In addition to these main areas, volume 3 contains an important idea which can be missed in our society. An essay by Lawless lays out this idea as the importance 
of the bio-region in our understanding of any place or history. Today, one of the many problems that people in industrialized countries face is a sense of alienation. Alienation in that people are separate from the land around them, that they are not really "home." Little big histories help us see the essence of the place we are in - the deep time story that led to everything we see. It makes each location come alive, making our home unique, glorious, and special instead of just a patch of ground. It also fosters appreciation for every location on Earth, by showing that all of them have their own stories that make them what they are today. Not only is this another much-needed realization brought by Big History, it is also simply true. This idea has been hinted at in essays throughout these three volumes, especially in volume 2 , where region after region was highlighted. This recognition of the importance and history of a location is one of the important concepts of Big History, and indeed of human existence. Unlike many concepts, there is not a goldilocks zone here. Local understanding has shaped many of us. This can be recognized in parallel to the also essential recognition of larger areas like the Earth or Milky Way as well as smaller areas like the cell and atom. The ability to see across orders of magnitude, both in space and time, is perhaps the most wonderful aspect of learning Big History, and this compendium of essays shows both the wide range and personal touch of Big History.

\section{Conclusion}

The essays in this three volume set give a wide view of Big History, giving both an understanding of Big History itself as well as a demonstration of the wide diversity of views within this growing and important field. For me, so many of these essays spoke to me personally and deeply, recalling my own meaning and purpose. Of course, each of us can find meaning and purpose in different ways and using different metaphors, but for me, the simple facts of our world are in no way "dry facts", but fantastic building blocks of a reality which gives both meaning and purpose.
Big History ties together these facts, which show that we are made of atoms forged in the awesome furnaces of ancient stars, and that we've evolved from simple molecules to cells to tiny cell colonies to aquatic worms to eels to fish clambering onto land, and so on to us. Big History, and the understanding of our history, transformed my world from a pointless, bewildering struggle into an invigorating challenge. The evidence gives my life incredible meaning and purpose. I marvel at my family tree, which goes back though innumerable life forms, through amazing stories of survival, hope, courage, and parental love. It includes the tiny mammal, surviving through the freezing, yearlong darkness after the asteroid impact by eating, and likely hiding in, a frozen dinosaur carcass, it includes the first mother to produce milk, and the first blurry view through a newly evolved eye. Our actual history has shown me that all life on earth is my family, bonded to me through billions of parental links of love. Realizing this gives the deep forest the same warmth and comfort as the family reunion which it is.

Feeling the gratitude toward countless Ancestors for my own existence, I feel the need to "pay it back" - but of course I can't, because those Ancestors are no longer alive. Instead we can all "pay it forward" by working to build a just and sustainable world. It could happen after centuries of environmental disasters, bloody wars, and untold suffering, or it could happen sooner, through our efforts to build a loving, rational culture focused on this world. It's up to us to choose when we'll get there. My family, your family, and indeed our family - including all life on earth - will live with the consequences tomorrow of the decisions we make today. Many of these essays, and the wider field of Big History, help me see that. May they do so for you as well. 
